\title{
Brownseed Paspalum Response to Season of Burning
}

\author{
C.J. SCIFRES AND K.W. DUNCAN
}

\section{Abstract}

Season of burning as related to plant phenology, maximum temperatures achieved, and soil water content rather than duration of heat exposure $(5,15$ or 30 seconds) apparently regulated fireinduced mortality of brownseed paspalum. Burning or top removal by clipping to ground line during the summer caused greatest mortality of brownseed paspalum and reduced herbage volume of surviving plants, whereas burning in early or mid-spring resulted in favorable growth responses. Fall burning was less damaging than summer burning but caused greater mortality of brownseed paspalum than did burning in the spring. Regrowth of brownseed paspalum after spring burning was equivalent to that following top removal by clipping during the same season. However, responses to summer or fall burning indicated that heat-induced damage (and/or perhaps subsequent winter kill following fall burns) occurred in addition to the effects of simple top removal.

Brownseed paspalum (Paspalum plicatulum Michx.) is a native, warm-season perennial bunchgrass which occurs throughout the eastern and central regions of Texas (Gould 1978) on soils ranging from sands to heavy clays. It is usually most abundant on sandy soils of prairies (Gould and Box 1965) and frequently occurs in partial shade in open oak woodlands in the Texas Post Oak (Quercus stellata) Savannah.

Brownseed paspalum produces stems 50 to $100 \mathrm{~cm}$ tall with firm, stout bases (Gould 1978). It is considered of fair grazing value for livestock (Gould and Box 1965). Since it initiates growth earlier than most warm-season species, brownseed paspalum is grazed most heavily in the spring (Durham and Kothmann 1977).

In much of the southeastern True Prairie (Stipa-Sporobolus) and Coastal Prairie (Stipa-Andropogon), brownseed paspalum often increases on sites where climax decreaser grasses are heavily grazed (Gould and Box 1965). In such situations, brownseed paspalum appears to replace characteristic dominants of good-toexcellent grazing value such as little bluestem (Schizachyrium scoparium), big bluestem (Andropogon gerardii), dropseeds (Sporobolus spp.), longspike silver bluestem (Bothriochloa saccharoides var. longipaniculata) and other mid- and tallgrasses. Continued heavy grazing in the Post Oak Savannah usually results in replacement of brownseed paspalum stands with species such as red lovegrass (Eragrostis oxylepis), broomsedge bluestem (Andropogon virginicus), and other grasses of low grazing value.

Although increasing abundance of brownseed paspalum can often be linked to a history of overgrazing of more desirable species, the species is also common on protected areas in the Post Oak Savannah where absence of grazing and fire has allowed excessive accumulation of mulch and the vegetation has become "stagnant." Brownseed paspalum is also common in abandoned fields and along roadsides in the area.

\footnotetext{
Authors are professor and graduate research assistant, Texas Agricultural Experiment Station (Department of Range Science). Texas A\&M University, College Station, 77843. The authors deeply appreciate the efforts of Julia Scifres in typing and preparation of the manuscript, and the aid of W. Carl Mohr in plot installation and evaluation. Approved by the Director, Texas Agricultural Experiment Station as TA-16126.

Manuscript received June 25, 1980.
}

Prescribed burning is an effective means of improving the production and utilization of range forages (Wright 1974), and is presently being used by some producers in east-central and southeast Texas to improve the botanical composition of native grasslands. However, season of burning is an important consideration when assessing the impact of burning on species composition of rangeland, especially as it relates to differential tolerances between warm-season and cool-season grasses (Wright 1978). Knowledge of interactions between season of burning and plant susceptibility is necessary to predict subsequent botanical shifts within plant communities. The objective of this study was to evaluate season of burning, duration of heat exposure, and their interaction on susceptibility of brownseed paspalum to fire.

\section{Materials and Methods}

The research was conducted on the Texas A\&M University Range Research Area near College Station on typical Post Oak Savannah rangeland. The soil is a fine sandy loam of the Tabor series, a member of the fine, montmorillonitic, the rmic family of Udertic Paleustalfs. The site has not been grazed or was grazed only lightly during the summers for 18 years. The study site was not grazed for the duration of the experiment. Vegetation was dominated by brownseed paspalum and willow baccharis (Baccharis salicina), with scattered plants of little bluestem, southern dewberry (Rubus trivalis), and various forbs such as southern thistle (Cirsium texanum var. texanum), western ragweed (Ambrosia psilostachya), and Baldwin ironweed (Vernonia baldwinii).

During the spring (April 27, 1978), summer (August 8, 1978), fall (October 4, 1978) and early spring (March 14, 1979), from 250 to 400 brownseed paspalum plants were marked with numbered metal tags and grouped into sets of 30 to 50 each. Two sets of plants were established in April 1978 for untreated comparisons. Two randomly selected sets of plants were burned on each date for 5,15 , or 30 seconds with a portable burner (Britton and Wright 1979) operated at $1.4 \mathrm{~kg} / \mathrm{cm}^{2}$ gas pressure. Temperature-sensitive pellets with melting points ranging from 28 to $648^{\circ} \mathrm{C}$ in $38^{\circ} \mathrm{C}$ increments were fixed on an asbestos sheet and placed in the burner at about 3 $\mathrm{cm}$ from ground line for at least three randomly selected burning durations on each date of burning.

Prior to burning in May and October 1978, and in April 1980. the basal circumference and height of each plant were recorded. Plant height and basal circumference measurements were used to calculate herbage volume $\left(\pi r^{2} h\right)$ to facilitate nondestructive sampling. Also, topgrowth of two randomly selected sets of plants was harvested to ground line on each treatment date. The clipped plants served for comparison of the effects of simple top removal versus heat-induced damage (Wright 1970), and for estimates of the proportions of live and dead tissues (oven-dry weight) and water content (\%) of the herbage on each treatment date. Clipped herbage was weighed immediately after harvesting, oven-dried at $60^{\circ} \mathrm{C}$ for 48 hours, and reweighed.

Environmental variables monitored at the time of burning included air-temperature; soil temperatures at the surface, $2 \mathrm{~cm}$, 
Table 1. Mortality (\%) of brownseed paspalum plants in October, 1979, after buming at various times for three durations near College Station, Texas.

\begin{tabular}{lcccccc}
\hline & \multicolumn{4}{c}{ Months after burning at various seasons ${ }^{1}$} \\
\cline { 2 - 3 } $\begin{array}{l}\text { Duration of } \\
\text { burn (sec) }\end{array}$ & Spring & $\frac{\text { Summer }}{14}$ & Fall & $\begin{array}{c}\text { Early- } \\
\text { spring }\end{array}$ & $\begin{array}{c}\text { Duration } \\
\text { avg }\end{array}$ \\
\hline None (clip) & $5 \mathrm{a}$ & $43 \mathrm{c}$ & $13 \mathrm{a}$ & $13 \mathrm{a}$ & $19 \mathrm{r}$ \\
5 & $4 \mathrm{a}$ & $83 \mathrm{e}$ & $52 \mathrm{~cd}$ & $12 \mathrm{a}$ & $38 \mathrm{~s}$ \\
15 & $11 \mathrm{a}$ & $93 \mathrm{e}$ & $55 \mathrm{~d}$ & $14 \mathrm{ab}$ & $43 \mathrm{~s}$ \\
30 & $8 \mathrm{a}$ & $93 \mathrm{c}$ & $50 \mathrm{~cd}$ & $24 \mathrm{~b}$ & $44 \mathrm{~s}$ \\
Season avg & $7 \mathrm{x}$ & $78 \mathrm{z}$ & $43 \mathrm{y}$ & $16 \mathrm{x}$ & \\
\hline
\end{tabular}

tSeason $X$ duration-of-burning means, average of season effects or average of duration effects followed by the same letter are not significantly different at $P \leqq 0.05$. Unburned plant mean $=0$ a

and $7 \mathrm{~cm}$ deep; relative humidity; and instaneous wind speed at 2 m. Also, triplicate soil samples were taken from 0 to 3,3 to 8 , and 8 to $15 \mathrm{~cm}$ deep for gravimetric determination of soil-water content at each date of burning.

\section{Results and Discussion}

Season-of-burning $\times$ duration-of-exposure interactions were not significant ( $P \leq .05$ ), regardless of attribute ( $\%$ mortality, herbage volume) used to evaluate the response of brownseed paspalum to burning. Duration of exposure to fire with the time periods evaluated was less important than season of burning. Fewest brownseed paspalum plants were killed by burning in early or mid-spring and the highest percentage apparent mortality (no regeneration from the plant bases) occurred after burning in the summer (Table 1). Percentage mortality estimates in April 1980, 13 months after the burns in early spring, were not significantly different from thosc in October 1979 (data not shown).

No more brownseed paspalum plants were killed by burning than by simple top removal in the spring, except where burning duration was 30 seconds and applied in early spring (Table 1). Burns in the spring were applied to plants averaging $21 \mathrm{~g}$ topgrowth, $25 \%$ of which was green tissue (Table 2). Average topgrowth water content was $27 \%$, and soil-water contents ranged from 18 to $26 \%$ in the surface $15 \mathrm{~cm}$ at the time spring burns were conducted (Table 3). About $22 \mathrm{~cm}$ of rain were received during the 60 days immediately prior to burning in the spring. The first significant rain after burning, almost $3 \mathrm{~cm}$, occurred 3 days after treatment application.

Maximum fire temperatures in the spring ranged from $216^{\circ} \mathrm{C}$ for the 5 - and 15 -second burns to $538^{\circ} \mathrm{C}$ for the 30 -second burns. The brownseed paspalum topgrowth usually continued burning for 10 to 15 seconds after installation of the 5-second burns. However, burning for 15 or 30 seconds completely consumed the topgrowth by the time the burns were terminated.

Average plant herbage volume was at least twice that of untreated plants, regardless of treatment, at 14 months after burning or clipping individual plant treatments in the spring (Table 4). Herbage volumes at 25 months after burning brownseed paspalum

Table 2. Fuel attributes of individual brownseed paspalum plants at the time of application of various burning treatments near College Station, Texas.

\begin{tabular}{lcccc}
\hline \hline \multirow{2}{*}{$\begin{array}{l}\text { Topgrowth attribute } \\
\text { (oven-dry) }\end{array}$} & \multicolumn{4}{c}{ Season of burn } \\
\cline { 2 - 5 } & Spring & Summer & Fall & Early-spring \\
\hline Total wt (g) & $21 \mathrm{ab}$ & $28 \mathrm{~b}$ & $28 \mathrm{~b}$ & $15 \mathrm{a}$ \\
Green tissue $(\%)$ & $25 \mathrm{~b}$ & $51 \mathrm{c}$ & $51 \mathrm{c}$ & $13 \mathrm{a}$ \\
Water content (\%) & $27 \mathrm{~b}$ & $12 \mathrm{a}$ & $14 \mathrm{a}$ & $20 \mathrm{ab}$ \\
\hline
\end{tabular}

'Means within row are not significantly different $(P \leqq .05)$ according to StudentNewman-Keul's test.
Table 3. Environmental variables associated with application of various burning treatments to brownseed paspalum near College Station, Texas.

\begin{tabular}{lcccc}
\hline \hline & \multicolumn{4}{c}{ Season of burn } \\
\cline { 2 - 5 } Environmental variable & Spring & Summer & Fall & $\begin{array}{c}\text { Early- } \\
\text { spring }\end{array}$ \\
\hline Air temperature (C) & 27 & 34 & 31 & 17 \\
Soil temperature (C), surface & 35 & 39 & 32 & 23 \\
$\quad 2 \mathrm{~cm}$ & 21 & 37 & 30 & 14 \\
$\quad 8 \mathrm{~cm}$ & - & 33 & 28 & 10 \\
Relative humidity (\%) & 41 & 37 & 55 & 36 \\
Wind, speed (km/hr) & $0-8$ & $0-11$ & $0-13$ & $8-16$ \\
$\quad$ direction (origin) & NE & SE & SE & N \\
Soil water content (\%) & & & & \\
$\quad 0-3$ cm & 23 & 2 & -1 & 23 \\
$3-8$ cm & 18 & 3 & - & 21 \\
$8-15$ cm & 26 & 4 & - & 20 \\
Precipitation & & & & \\
60 days preburn (cm) & 22 & 2 & 16 & 26 \\
60 days postburn (cm) & 18, & 16 & 18 & 29 \\
First rain postburn (days) & 3 & 12 & 21 & 6 \\
$\quad$ First significant rain & & & & \\
$\quad$ postburn ${ }^{2}$ (days) & 3 & 32 & 32 & 12 \\
\hline
\end{tabular}

'Samples destroyed in building fire.

${ }_{2}^{2}$ Arbitrarily defined at first storm to deliver at least $1.3 \mathrm{~cm}$ of rainfall in $8-\mathrm{hr}$ period.

in the spring (data not shown) were not different from those after 19 months. Herbage volume of untreated plants was 107 to $115 \mathrm{~cm}^{3}$ during the 1978, 1979, and 1980 growing seasons.

Clipping or burning in the summer was detrimental to brownseed paspalum. An average of $43 \%$ of the plants did not survive after mechanical top removal to ground line, whereas burning killed $83 \%$ to $93 \%$ of the plants (Table 1).

Wright (1971) attributed differences in fire resistance between squirreltail (Sitanion hystrix) and needle-and-thread (Stipa comata) to density of dead plant material in the bunches. The relative fire tolerance of squirreltail was attributed to the low density of dead material in the bunches, whereas needle-andthread bunches contained enough dead material to promote significant heat penetration to the growing points. However, the average amount of dead material in brownseed paspalum plants varied little from (13 to $16 \mathrm{~g}$ ) among the seasons of burning (Table 2). Therefore, the higher mortality after burns in the summer, compared to that in the spring, was attributed to environmental conditions during and following the burns.

Air and soil temperatures were relatively high at the time of burn installation in the summer, compared to the spring, and soil-water content averaged only 2 to $4 \%$ in the surface $15 \mathrm{~cm}$ (Table 3 ). Maximum temperatures at a height of $3 \mathrm{~cm}$ during the burns were 315,426 , and $593^{\circ} \mathrm{C}$ for the 5,15 , and 30 -second exposures, respectively. Only $2 \mathrm{~cm}$ of rainfall was received 60 days prior to the burns in the summer but normal fall rains $(16 \mathrm{~cm})$ for the area based on long-term precipitation records occurred during the 60day post-burn period. However, lack of significant rainfall for 32 days after burning the brownseed paspalum in the summer restricted vegetative growth until nearly mid-September.

Topgrowth volume of surviving plants, whether burned or subjected to mechanical top removal, was reduced at 9 and 14 months after application of the summer treatments (Table 4). However, by 21 months after burning in the summer, herbage volume of the few surviving brownseed paspalum exceeded that of untreated plants.

At 21 months after application of burns in the summer, little bluestem (Schizachyrium scoparium) seedlings had become established in 53\% of the areas previously occupied by brownseed paspalum. The remainder of the open areas were occupied by seedlings of broomsedge (Andropogon virginicus), Dicanthelium spp., Sporobolus spp., and various forbs. This suggests that summer burns might reduce the abundance of brownseed paspalum and increase the relative abundance of little bluestem in the 
Table 4. Average herbage volume as a percentage of untreated plants after burning or clipping brownseed paspalum at various seasons near College Station, Texas.

\begin{tabular}{|c|c|c|c|c|c|c|c|c|c|c|c|}
\hline \multirow{3}{*}{$\begin{array}{l}\text { Duration } \\
\text { of burn } \\
\text { (sec) }\end{array}$} & \multicolumn{11}{|c|}{ Months after burning at various seasons ${ }^{\prime}$} \\
\hline & \multicolumn{2}{|c|}{ Spring } & \multicolumn{3}{|c|}{ Summer } & \multicolumn{3}{|c|}{ Fall } & \multicolumn{3}{|c|}{ Early-spring } \\
\hline & $1 \overline{4}$ & 19 & 9 & 14 & 21 & 7 & 12 & 19 & $2 . \overline{4}$ & 7 & 14 \\
\hline $\begin{array}{c}\text { None (clip) } \\
5 \\
15 \\
30\end{array}$ & $\begin{array}{l}203 \mathrm{jjk} \\
224 \mathrm{kl} \\
213 \mathrm{jk} \\
224 \mathrm{kl}\end{array}$ & $\begin{array}{l}256 \mathrm{l}-\mathrm{o} \\
267 \mathrm{mno} \\
266 \mathrm{mno} \\
232 \mathrm{k}-\mathrm{n}\end{array}$ & $\begin{array}{l}46 \text { cde } \\
14 \text { a-d } \\
<1 \text { a } \\
<1 \text { a }\end{array}$ & $\begin{array}{l}46 \text { cde } \\
34 \mathrm{a}-\mathrm{e} \\
<1 \mathrm{a} \\
<1 \mathrm{a}\end{array}$ & $\begin{array}{l}221 \mathrm{kl} \\
234 \mathrm{k}-\mathrm{n} \\
269 \mathrm{no} \\
223 \mathrm{kl}\end{array}$ & $\begin{array}{l}6 a b c \\
4 a b \\
4 a b \\
8 a b c\end{array}$ & $\begin{array}{r}32 \mathrm{a-e} \\
10 \mathrm{abc} \\
8 \mathrm{abc} \\
14 \mathrm{a-d}\end{array}$ & $\begin{array}{l}251 \mathrm{l}-\mathrm{o} \\
213 \mathrm{jk} \\
268 \mathrm{mno} \\
258 \mathrm{l}-\mathrm{o}\end{array}$ & $\begin{array}{r}51 \mathrm{de} \\
127 \mathrm{gh} \\
63 \mathrm{ef} \\
43 \mathrm{~b}-\mathrm{e}\end{array}$ & $\begin{array}{l}167 \mathrm{hi} \\
132 \mathrm{hi} \\
178 \mathrm{ij} \\
116 \mathrm{~g}\end{array}$ & $\begin{array}{l}228 \mathrm{klm} \\
202 \mathrm{ijk} \\
233 \mathrm{k}-\mathrm{n} \\
288 \mathrm{o}\end{array}$ \\
\hline
\end{tabular}

IMeans followed by the same letter are not significantly different $(P \leqq .05)$ according to Student-Newman-Kuel's test. Unburned plant herbage volumes $=100 \mathrm{fg}$.

botanical composition, if selective grazing postburn was not a factor.

Clipping in fall or early spring killed $13 \%$ of the brownseed paspalum plants (Table 1). However, brownseed paspalum mortality from burning in the fall was at least $50 \%$ after 12 months, regardless of the duration of exposure to fire. Topgrowth fuel weight, percentage green tissue, and fuel-water content during the burns in the fall were the same as during the burns in the summer (Table 2). Air and soil temperatures were lower during the fall burns than during the summer treatments (Table 3). Precipitation was adequate following fall burns for development of 1 to $1.5 \mathrm{~cm}$ of new growth before first frost. The subsequent winter was abnormally harsh with air temperatures of less than $-6^{\circ} \mathrm{C}$ on several days accompanied by ice storms in December and January. These conditions may have contributed to mortality of fall-burned brownseed paspalum plants.

By the year after treatment, topgrowth volume of brownseed paspalum plants surviving fall burns was significantly reduced compared to that of untreated plants (Table 4). Since brownseed paspalum usually maintains some green tissues throughout the winter in this region, burning in the fall apparently reduced the chances of winter survival of new tillers. However, at 19 months after burning in the fall, average topgrowth volume of plants surviving the burns was more than double that of untreated plants.

The burn in the early spring was originally scheduled as a dormant-season burn. However, the abnormally wet winter, maintenance of some green tissues by brownseed paspalum during the winter, and early greenup prevented burning of truly dormant plants. With the exception of responses to burning for 30-seconds, brownseed paspalum mortality following burning in the early spring 1979 was similar to that from the burns in spring 1978 (Table 1). Because of the harsh winter, much of the standing dead plant material had dropped to the soil surface so that the standing fine fuel per plant averaged only $15 \mathrm{~g}$, of which $13 \%$ was live tissue (Table 2). Air temperatures were mild, and soil-water contents were 20 to $23 \%$ to a depth of $15 \mathrm{~cm}$ at the time of installation of the burns (Table 3). Because of reduced topgrowth weights and mild weather conditions, maximum temperatures $\left(243,300\right.$, and $298^{\circ} \mathrm{C}$ during 5,15 and 30 -second burns, respectively) were lower than those achieved during the fall or summer.

By 2.4 months after treatment in the early spring, brownseed paspalum topgrowth volume of clipped plants was about $50 \%$ of that of untreated plants but topgrowth volume of plants burned for 5 seconds was not significantly different from that of the untreated plants (Table 4). Topgrowth volume of plants burned for 15 seconds tended to be lower than that of untreated plants after 2.4 months, and was significantly reduced by the 30 -second exposure. However, herbage volume equalled or exceeded that of untreated plants after 7 months, regardless of treatment. At 14 months after burning in early spring, topgrowth volumes more than doubled those of untreated brownseed paspalum plants.

Burning brownseed paspalum during the summer or fall increases the chances of plant mortality, compared to burning in the spring. Brownseed paspalum responds most favorably to burning in early- to mid-spring under relatively mild, wet conditions. Effects of burning during spring are equivalent to the effects of mechanical top removal. Burning under dry conditions in the summer may reduce brownseed paspalum and increase little bluestem in the botanical composition of Post Oak Savannah rangelands.

\section{Literature Cited}

Britton, C.M., and H.A. Wright. 1979. A portable burner for evaluating the effects of fire on plants. J. Range Manage. 32:475-476.

Durham, A.J., and M.M. Kothmann. 1977. Forage availability and cattle diets on the Texas Coastal Prairie. J. Range Manage. 30:103-106.

Gould, F.W., and T.W. Box. 1965. Grasses of the Texas Coastal Bend. Texas A\&M Univ. Press, College Station, Tex. 189 p.

Gould, F.W. 1978. Common Grasses of Texas. Texas A\&M Univ. Press, College Station, TX. 267 p.

Wright, H.A. 1970. A method to determine heat-caused mortality in bunchgrass. Ecology 51:582-587.

Wright, H.A. 1971. Why squirreltail is more tolerant to burning than needle-and-thread? J. Range Manage. 24:277-284.

Wright, H.A. 1974. Range burning. J. Range Manage. 27:5-11.

Wright, H.A. 1978. Use of fire to manage grassland of the Great Plains: Central and southern Great Plains. Proc. Internat. Rangeland Congr. 1:694-696. 